\title{
Impact Of Information Disclosure Violation On Firm Value In Chinese Listed Firms
}

\author{
Bin Li, Xi'an Jiaotong University, China
}

\begin{abstract}
We analyze the association between information disclosure violation (IDV) and firm value, based on a sample of Chinese listed firms that were subject to China Securities Regulatory Commission (CSRC) enforcement actions from 2000 to 2014. Using Tobin's $Q$ as a proxy for firm value at the end of the enforcement action year, we find that firm value in violating firms is significantly lower than firm value in non-violating firms. Further, we find IDV with the following characteristics can cause serious damage to firm value: IDV related to inflated profit or asset fabrication have a more damaging effect on firm value; the total number of violation types, fines and the total number of admonishment types are negatively associated with firm value; violation frequency and number of years between violations and CSRC enforcement action are negatively related to firm value.
\end{abstract}

Keywords: Violation; Information Disclosure; Firm Value; China Securities Regulatory Commission (CSRC) Enforcement Action

\section{INTRODUCTION}

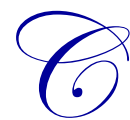
hina is the second largest economy in the world, with astonishingly rapid growth admired by other countries. However, it is frequently noted that many listed firms are punished for failing to disclose information as required. For example, Yunnan Green-Land Biological Technology Co., Ltd (Code: 002200) is suspected of inflating profit and asset fabrication. Yunnan Green-Land revised its profit forecast frequently, changing estimated income for 2009 from $¥ 62$ million on Feb 27, 2010, to $¥-151$ million on April 30, 2010 .

Corporate transparency, honesty, governance, and monitoring and regulation of listed firms are major concerns for Chinese investors (Anderson, 2000).

A great nation with lots of fraud, violations, or irregularity issues in its capital markets may be doomed to eventual failure, no matter how fast it is developing. The Toshiba financial scandal of 2015, an example of channel stuffing, is notable. The tremendously important issue of egregious firm violations makes many investors, capital market regulators, and researchers realize the importance of IDV.

Adverse market reaction to IDV or China Securities Regulatory Commission (CSRC) enforcement action has been documented extensively in the literature (e.g., Smith et al., 1984; Feroz et al., 1991; Ferris et al., 1992; Chen et al., 2005; Heflin and Hsu, 2008; Muradoglu and Huskey, 2008). However, these researchers are more concerned with the economic consequences of IDV from a short-run perspective, neglecting the potential long-run damaging consequences from IDV, which may be incorporated or assimilated into the market. A stock price reaction can result from changes in expectations of future cash flows or changes in the discount rate, or both. Thus, studying the consequences of IDV can bring about more robust understanding of such reactions.

In the Chinese capital markets, types of IDV include inflated profit, asset fabrication, fines by regulatory authorities and others. It is difficult to distinguish these violations from opportunistic behavior or daily mistakes. Also, many listed firms are marked with several types of violation, and have multiple violations, as well as long time span (the period from when a firm commits a violation to the announcement date on which the CSRC publishes an enforcement action). Regulators seek to improve efficiency in capital markets (Healey and Palepu, 2001) and level the playing field through mandatory disclosure (Zhu and Gippel, 2015). Further, regulatory agencies such as the 
CSRC may pursue alternative measures (e.g., public criticism, public condemnation, warnings, and fines) to punish culprit firms according to violation type and severity. However, these latter violation measures have not been fully explored in the literature (Chen et al., 2005)

This paper examines the impacts of IDV on firm value; specifically, it tests whether firm value is lower in violating firms than in non-violating firms. It also examines whether firm value varies with violation characteristics, such as violation types like inflated profit, categories of types (such as inflated profit, asset fabrication, false statement and others), fines by regulatory institutions (CSRC, Shanghai Stock Exchange, Shenzhen Stock Exchange), type of enforcement (public criticism, public condemnation, warning, fine), violation frequency, and violation time span. We restrict our sample to first-time violation disclosures, as these should be more consequential for insider trading and stock return than subsequent violations, as reported by Gopalakrishnan and Parkash (1995), Dichev and Skinner (2002), Demiroglu and James (2010), and Griffin et al. (2014).

As described below in H5, the adverse economic consequences brought about by IDV are not temporary; they are quite long-lasting. However, many listed firms may underestimate this long-term potential hazard; their managements may regard violations as less serious, leading to frequent violations. Against this background, it seems appropriate to study now the economic consequences of IDV from a long-run perspective.

Overall, testing the impact of IDV on firm value in the Chinese capital markets holds several important implications. First, it allows us to test whether IDV negatively affects firm value in emerging markets. To date, the impact of IDV on firm value has not been sufficiently studied. Development of Chinese Standard Inspective Procedure (SIP) is still in progress, leading to firm value calculation that differs from that of the US. Further, different shareholder classes in China have distinct incentives and abilities to monitor management; large shareholders in particular have absolute controlling power through their non-tradable shares. ${ }^{1}$ Large shareholders themselves may give instructions to or exert political influence over management, who may hold critical information or carry out entrenchment actions through information asymmetry, so the adverse effect of IDV may infringe only upon minority shareholders. In addition, political considerations always dominate, shadowing irregularities in culprit firms (Anderson, 2000). These considerations make Chinese IDV divergent from other countries' settings. Therefore, by examining the impact of IDV in the Chinese context, we can extend and complement the literature on information disclosure.

Second, research on the effect of IDV on firm value takes mainly a short-run perspective, around announcement of enforcement action by the CSRC. Chen et al. (2005), Heflin and Hsu (2008), Muradoglu and Clark (2008), and Murphy et al. (2009) document a downward earnings expectation for investors after IDV disclosure. These researchers neglect the long-term effect, which may be incorporated or assimilated into the market. Stock price reaction can result from changes in expectations of future cash flows or changes in the discount rate, or both; thus, we examine firm value at the end of the enforcement year, which may provide a much more advantageous tool to examine the effect of IDV from a steadier perspective. To the best of our knowledge, our paper is the first to relate IDV to firm value in the long run.

Third, we examine the relationship between firm value and violation characteristics, such as violation type (e.g., inflated profit, total number of violation types, types of admonishment (e.g., fines), violation frequency, and violation time span). Our research extends and complements the theory of IDV, providing input into future policy deliberations by regulators.

The remainder of this paper proceeds as follows. Section 2 discusses relevant literature and sets forth our empirical predictions. Section 3 describes our sample and research design. Sections 4 and 5 present the empirical results and additional analyses, respectively, and Section 6 details our conclusions.

\footnotetext{
${ }^{1}$ Non-tradable shares can be bought and sold only through private placement with special approval from the government. The non-tradable restriction is to uphold the fundamental doctrine of socialism that all economic means belong to the people so that "no person is allowed to sell out socialism."
} 


\section{LITERATURE REVIEW AND HYPOTHESIS DEVELOPMENT}

\section{Effects of IDV on Capital Markets}

The effects of IDV have not been studied extensively, even in developed markets. Smith et al. (1984), Feroz et al. (1991), Howe and Schlarbaum (1986), and Nourayi (1994, 1995) examine Securities and Exchange Commission (SEC) enforcement actions and confirm a small negative market reaction upon disclosure of violations. Karpoff et al. (2008) find that firms lose $41 \%$ of their market value when news of misconduct is revealed. Murphy et al. (2009) find that decreases in earnings and increases in risk accompany allegations of misconduct between January 1982 and December 1996. Further, some researchers study IDV from a legal perspective. Using 269 events between 1995 and 2004, Muradoglu and Clark (2008) examine the effect of announcement of SEC legal enforcement actions, finding that SEC lawsuits have a negative effect on share price. Their results also show that the markets are able to differentiate between minor and major violations, and cases related to fraud and insider trading, which lead to more damaging consequences than procedural violations and improper accounting. However, these studies focus exclusively on IDV in mature markets, neglecting the distinct mechanisms inherent in diverse systems and institutions all over the world.

Regulation in China stems from the CSRC. The CSRC is the sole supervisor of the financial markets and public firms in China; it initiates investigations based on a number of leads. These leads include complaints from investors, information from insiders or former employees of firms, the media, and analyses of annual reports and other corporate disclosures, along with referrals from stock exchanges, legal disputes, and police investigations (Chen et al., 2005). CSRC investigations lead to sanctions and enforcement action (similar to Accounting and Auditing Enforcement Releases in the US) reports when firms or their managements are found to be involved in fraud or other irregularities.

Also, Chinese share issue privatization has created different classes of shares, namely state, institutional, foreign, insider, individual, and employee shares. These shareholders differ in their interests in the firm and their incentives and ability to monitor management (Wei et al., 2005). Further, in China's economic transition, literally all listed firms were carved out of state-owned enterprises (Yao et al., 2010), and numerous shares of many public firms are owned by the state and its associated ministries (Chen et al., 2005). Such large shareholders have absolute controlling power via their non-tradable shares. Corporate governance in China is still developing and can be characterized as weak shareholder protection and underdeveloped markets for corporate control (LaPorta et al., 1999). Reducing information asymmetry between informed and uninformed investors is an important issue for investors and regulators. Many studies find that disclosure of information decreases information asymmetry (Chiyachantana et al., 2004; Eleswarapu et al., 2004; Gintschel and Markov, 2004; Shroff et al., 2013). There is evidence that shareholders with better access to analyst recommendations earn significant abnormal returns from trading on such information (Lepone et al., 2013; Zhu and Gippel, 2015).

Managerial ownership in China is minimal and insiders can gain control either through direct government appointments or indirect political influence. IDV may be directed by large shareholders themselves (by giving instructions to or exercising political influence over management, directly or indirectly), so the adverse effect of IDV may infringe only upon minority shareholders. Further, given that China is still a fundamentally socialist country ruled by the Communist Party, political considerations always dominate, shadowing irregularities in suspect firms. This means that when IDVs are exposed publicly, government intervention may help violating firms understate their mistakes. These factors make Chinese IDV divergent from other settings.

\section{Adverse Effects from IDV}

Negative and adverse effects from IDV may be harmful to firm development in the long run (Karpoff et al., 2008). However, most research on the consequences of IDV are from a short-run perspective, neglecting potential dangerous consequences in the long run, which ought to keep culprits from offending to some extent. To fill this void and to have managements understand the severity and harm of IDV to firm development, this paper examines the impact of IDV on firm value based on the Chinese capital market. Therefore, we expect that firm value is negatively affected by IDV, and we state our first hypothesis as follows: 
H1: Firm value in violating firms is substantially lower than firm value in non-violating firms.

\section{Relationship Between Violation Characteristics and Firm Value Among IDV Companies}

Chen et al. (2005) research IDV under investigations of the CSRC in the Chinese capital markets in the period 1999 to 2003. These authors find that enforcement actions by the CSRC have a negative impact on stock prices, with most firms suffering wealth losses of around $1 \%$ to $2 \%$ in the five days following the event. Further, they divide samples by type of enforcement (public criticism, public condemnation, warning, and fine), by regulatory institution (CSRC, Shanghai Stock Exchange, Shenzhen Stock Exchange), and by type of violation (illegal share buyback, inflated profit, asset fabrication, unauthorized fund use change, postponement/delay in disclosure, false statement, fund provision violation, major failure to disclose information, major shareholder embezzlement, and others). They find that public condemnations and warnings attract more severe price reactions than do the most serious sanctions (fines), and only major failure to disclose information has a negative impact on stock returns. Regrettably, Chen et al. (2005) fail to fully explore the reasons for the effect on stock return by violation characteristics.

First, we analyze the relationship between violation types and firm value. Inflated profit and asset fabrication are experienced by most companies. Inflated profit and asset fabrication directly relate to financial statement manipulation by management, which can decrease management integrity sharply, causing investors to divert their resources. Also, Feroz et al. (1991) find that revenue recognition and overstatement of current assets draw the most SEC attention.

H2a: Decreasing firm value caused by IDV is more pronounced for IDV firms with inflated profits or asset fabrication case than for IDV firms with other violation types.

The more violation types firms experience, the lower their firm value. Thus, we set forth the following hypothesis.

H2b: IDV firm value is negatively related to the total number of violation types.

Second, we analyze the relationship between admonishment type and firm value. CSRC enforcement actions include public criticism, public condemnation, official warning, and monetary fines. The first two are the mildest forms of admonishment, followed by official warning and then fine (Chen et al., 2005). Fine is the most common admonishment type used by the CSRC. Therefore, we present the following hypotheses:

H3a: Decreasing firm value caused by IDV is more pronounced for IDV firms being fined than for IDV firms with other admonishment types.

H3b: Firm value of IDV companies is negatively related to the total number of admonishment types.

Third, we analyze the relationship between violation frequency and firm value. Firms with multiple violations are an indication that there are material deficiencies in internal control and that management integrity cannot be relied upon, which may bring more damage to firm value. Therefore, we present the following hypotheses:

H4: Firm value of IDV companies is negatively related to violation frequency.

Finally, we consider the long-term effect of violation. The presence of detected violations at earlier times suggests that prior financial statement or material business transactions are not entirely correct, and the later the violation is exposed, the more periods are influenced, and the more investors are deceived. Thus, we present the following hypotheses:

H5: Firm value of IDV companies is negatively related to time span from the year of violation to the year of exposure.

Figure 1 depicts the relationship between IDV and firm value. 
Figure 1. Framework for Relationship between IDV and Firm Value

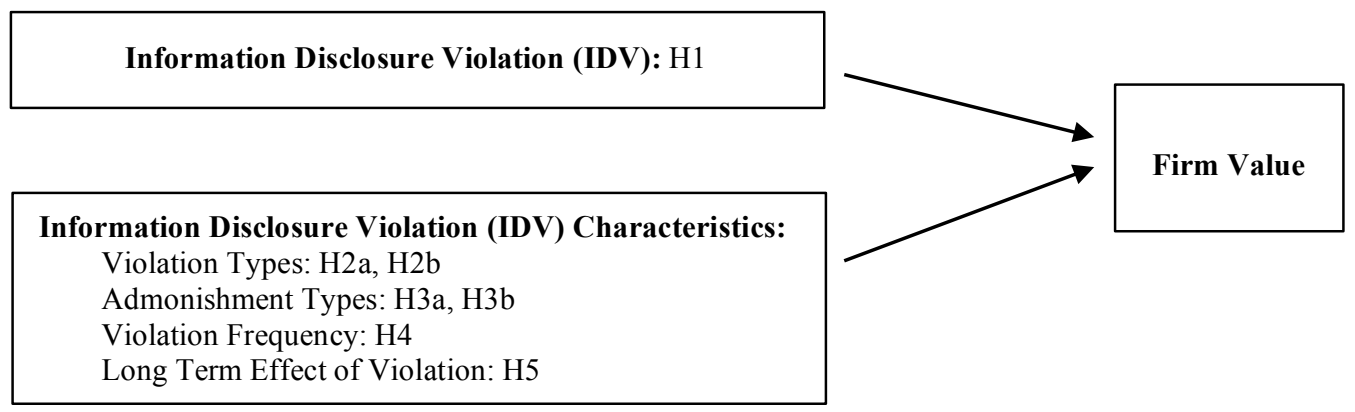

\section{SAMPLE AND METHODOLOGY}

We examine the impact of IDV on firm value in listed firms. We then examine whether some violation types have more severe consequences than others. We also develop a pooled cross-sectional model to explain our research.

\section{Sample}

We first match the CSMAR database ${ }^{2}$ and IDV sample based on stock code and IDV year. Connecting these two elements allows us to identify the basic characteristics of IDV firms, including industry, size, financial ratio, and ownership structure. We require that each observation have valid data from the CSMAR database. Further, we ensure that these non-violating observations have no IDV cases during the period chosen. To achieve comparability among all firms, we focus only on the A-share market, excluding the B-share market. This is because B-share firms differ from A-share firms in many respects, such as listing and delisting conditions, disclosure requirements. Merging the CSMAR database and the IDV sample results in a sample of 1,623 identified observations of IDV relative to 14,343 non-restatement observations of public companies.

\section{Methodology}

We empirically investigate the impact of IDV on the capital markets. We take IDV exposure year as our baseline research year and establish whether firm value is significantly lower in violating firms than in non-violating firms. To test our hypotheses, we take Tobin's Q as a proxy for firm value at year-end. Following Wei et al. (2005), our primary valuation measure, Tobin's $\mathrm{Q}(T O B I N Q)$, is computed as the sum of market value of equity and book value of debt, divided by book value of assets. ${ }^{3}$ We winsorize $T O B I N Q$ at the $5^{\text {th }}$ and $95^{\text {th }}$ percentiles to alleviate the influences of extreme outliers.

To test our hypotheses, we use two ordinary least square regression models. While Model (1) investigates the association between IDV and firm value for H1, Model (2) tests the relationship between violation characteristics and firm value among IDV firms for $\mathrm{H} 2-\mathrm{H} 5$.

$$
\begin{aligned}
& \text { TOBINQ }=\beta_{1} I D V+\beta_{2} R O A+\beta_{3} G R O W+\beta_{4} L E V+\beta_{5} L N A+\beta_{6} A O+\beta_{7} B I G 4+\beta_{8} H I+\beta_{9} S S+\beta_{10} T S \\
& +\beta_{11} D U A L+\beta_{12} B S I Z E+\beta_{13} O S I Z E+\Sigma I N D+\Sigma Y E A R+\varepsilon \\
& \text { TOBINQ }=\beta_{1} V I C+\beta_{2} R O A+\beta_{3} G R O W+\beta_{4} L E V+\beta_{5} L N A+\beta_{6} A O+\beta_{7} B I G 4+\beta_{8} H I+\beta_{9} S S+\beta_{10} T S \\
& +\beta_{11} D U A L+\beta_{12} B S I Z E+\beta_{13} O S I Z E+\Sigma I N D+\Sigma Y E A R+\varepsilon
\end{aligned}
$$

The dependent variable for Model (1), IDV, is classified as either experiencing an IDV (=1) or non-experiencing

\footnotetext{
${ }^{2}$ This database is commercially available at Shenzhen GTA Information Technology Company Ltd. Also, firm value data and other data are collected from the CSMAR database, including Tobin's Q and other market valuation indicators, financial ratios, corporate governance data and other data in connection with Chinese listed firms.

${ }^{3}$ Here, market value of equity of non-tradable shares is substituted by net assets.
} 
$(=0)$. The dependent variable for Model (2), VIC, refers to violation characteristics, which includes inflated profit or asset fabrication $(I P A F)$, total number of violation types (TNT), fines (FINE), total number of admonishment types $(N A T)$, violation frequency $(V F)$, and year span between violation and exposure $(Y S P A N)$. The IPAF variable is an indicator for whether the firm relates inflated profits or asset fabrication. The $T N T$ variable is the total number of types of IDV. The FINE variable equals 1 if the firm relates to the admonishment type, that is, fine, zero otherwise. The $N A T$ variable is the total number of admonishment types. The $V F$ variable is the frequency of violation. The $Y S P A N$ variable is the time span between violation year and exposure year.

To control for the effect of profitability and growth, we use ROA and GROW. ROA is measured as earnings divided by equity, and GROW is asset growth before the IDV exposure year. We control for firm leverage, represented by $L E V$, measured as liabilities divided by assets. Ceteris paribus, higher leverage is related to higher risk, which may affect firm value. $L N A$ is natural logarithm of total assets, which controls for firm size. To control for the effect of external audit, we use $A O$ and $B I G 4 . A O$ is an indicator variable that equals one if the firm is issued an unqualified auditor opinion, zero otherwise. $B I G 4$ is an indicator variable that equals 1 if the firm is audited by "Big4" auditors, zero otherwise. Prior studies such as Wei et al. (2005) document that TOBINQ is affected by ownership concentration in China, so we include $H I$, a Herfindahl index, as a proxy for ownership concentration. Further, state share $(S S)$ is considered, depicting ownership of state-owned enterprise. $S S$ is measured by percentage ownership by the state; otherwise $S S$ equals zero. Trading share (TS) is also considered, represented by $T S$, depicting tradable shares. TS is an indicator variable that equals 1 after the year end of 2005, when Equity Division Reform began to be enforced by the SEC. Thus, TS equals zero before 2005. DUAL is an indicator variable that equals 1 if the CEO takes the role of chairman of the board, zero otherwise. BSIZE and OSIZE represent board size and supervisory size, respectively. Finally, industry and year differences are included in regressions. All variables used in this paper are defined in Table 1 below.

Table 1. Variables and Definitions

\begin{tabular}{|c|c|}
\hline Variable & Definition \\
\hline \multicolumn{2}{|c|}{ Dependent Variables } \\
\hline TOBINQ & The sum of market value of equity and book value of debt, divided by book value of assets \\
\hline \multicolumn{2}{|c|}{ Independent Variables } \\
\hline IDV & $\begin{array}{l}\text { An indicator variable that equals one when the firm relates to information disclosure violation, and } \\
\text { zero otherwise }\end{array}$ \\
\hline IPAF & $\begin{array}{l}\text { An indicator variable that equals one when the firm relates to inflated profits or asset fabrication, and } \\
\text { zero otherwise }\end{array}$ \\
\hline TNT & The total number of types of IDV which the firm is experienced \\
\hline FINE & $\begin{array}{l}\text { An indicator variable that equals one when the firm relates to the admonishment type which is fine, } \\
\text { and zero otherwise }\end{array}$ \\
\hline NAT & The total number of admonishment types experienced by the firm \\
\hline VF & Violation frequency between violation year and exposure year \\
\hline YSPAN & Timespan between violation year and exposure year \\
\hline \multicolumn{2}{|l|}{ Control Variables } \\
\hline ROA & Earnings divided by equity, to control for the effect of profitability and growth \\
\hline GROW & Asset growth before IDV exposure year, to control for the effect of growth \\
\hline LEV & Liabilities divided by assets, to control for firm leverage \\
\hline LAN & Natural logarithm of total assets, to control for firm size \\
\hline $\mathrm{AO}$ & $\begin{array}{l}\text { An indicator variable that equals one if the firm is issued an unqualified auditor opinion, zero } \\
\text { otherwise }\end{array}$ \\
\hline BIG4 & An indicator variable that equals one if the firm is audited by "Big4" auditor, zero otherwise \\
\hline $\mathrm{HI}$ & Herfindahl index, as a proxy for ownership concentration \\
\hline SS & State ownership in percent if under state control, zero otherwise, if it is not controlled by state \\
\hline TS & An indicator variable that equals one after 2005 , zero otherwise \\
\hline DUAL & $\begin{array}{l}\text { An indicator variable that equals one if the CEO takes the role of chairman of the board, zero } \\
\text { otherwise }\end{array}$ \\
\hline BSIZE & Board size \\
\hline OSIZE & Supervisory board size \\
\hline
\end{tabular}




\section{EMPIRICAL RESULTS}

\section{Descriptive Statistics}

Table 2 details the distribution of our IDV sample by year and initiator. It is apparent that IDVs are investigated and exposed mainly by the CSRC and the two major exchanges. Further, it is evident that IDV exposure increases after 2001, increasing rapidly from 2012, and peaking in 2013 and 2014. Additionally, it is evident from Table 2 that IDVs are also exposed by other supervisors from 2006. The number of IDV samples exposed by "other" supervisors increased to 83 in 2013; this number increased in 2014 to 96.

Table 2. Distribution of the IDV Sample by Year and Initiator ${ }^{*}$

\begin{tabular}{|c|c|c|c|c|c|c|}
\hline Year & $\operatorname{CSRC}^{1}(\%)$ & $\begin{array}{c}\text { Shanghai } \\
\text { Exchange (\%) }\end{array}$ & $\begin{array}{c}\text { Shenzhen } \\
\text { Exchange (\%) }\end{array}$ & $\begin{array}{c}\text { Ministry of } \\
\text { Finance }^{2}(\%)\end{array}$ & Other $^{3}(\%)$ & Total (\%) \\
\hline 2000 & 3 & 2 & 2 & 0 & 0 & $7(0.43)$ \\
\hline 2001 & 12 & 18 & 17 & 0 & 0 & $47(2.90)$ \\
\hline 2002 & 8 & 19 & 15 & 1 & 0 & $43(2.65)$ \\
\hline 2003 & 8 & 15 & 14 & 0 & 0 & $37(2.28)$ \\
\hline 2004 & 4 & 17 & 17 & 0 & 0 & $38(2.34)$ \\
\hline 2005 & 36 & 12 & 23 & 0 & 0 & $71(4.37)$ \\
\hline 2006 & 27 & 10 & 22 & 1 & 1 & $61(3.76)$ \\
\hline 2007 & 26 & 10 & 14 & 3 & 4 & $57(3.51)$ \\
\hline 2008 & 14 & 7 & 26 & 2 & 11 & $60(3.70)$ \\
\hline 2009 & 37 & 4 & 37 & 1 & 34 & $113(6.96)$ \\
\hline 2010 & 43 & 10 & 54 & 1 & 37 & $145(8.93)$ \\
\hline 2011 & 46 & 2 & 68 & 4 & 53 & $173(10.66)$ \\
\hline 2012 & 62 & 7 & 81 & 0 & 78 & $228(14.05)$ \\
\hline 2013 & 69 & 16 & 86 & 4 & 83 & $258(15.90)$ \\
\hline 2014 & 83 & 27 & 77 & 2 & 96 & $285(17.56)$ \\
\hline Total & $478(29.45)$ & $176(10.84)$ & $553(34.07)$ & $19(1.18)$ & $397(24.46)$ & $1623(100)$ \\
\hline
\end{tabular}

Notes: ${ }^{*}$ The numbers in parentheses in the right column of Table 2 refer to the percentage of IDV samples of each year in the total number (1623); Bottom numbers in parentheses represent the percentage of IDV samples found by different initiators in the total number (1623).

1 "CSRC" also includes the Resident Office of China Securities Regulatory Commission in every province of China.

2 "Ministry of Finance" includes the Resident Office (TePaiBan) in every province in China.

3 "Other" includes: National Environmental Protection Bureau, Bureau of Industry and Information Technology; local securities regulatory bureaus, such as the Beijing Securities Regulatory Bureau, the Shenzhen Securities Regulatory Bureau, Fujian Securities Regulatory Bureau; the Industrial and Commercial Administration Bureau, the departments of environmental protection of every province of China.

Table 3 shows descriptive statistics of the violating and non-violating firms. The mean TOBINQ is 1.439 for the IDV group, lower than the 1.457 for the non-violating group, showing that firm value may be adversely affected by IDV. Further, violating firms have higher profitability, slower growth, and higher leverage, greater likelihood of being issued an unqualified auditor opinion, smaller ownership concentration, higher state ownership, and lower percentage of tradable shares. 
Table 3. Characteristics of IDV and Non-violating Sample

\begin{tabular}{|c|c|c|c|c|c|c|}
\hline Variable & $I D V$ & Mean & Std. Dev. & Min. & Max. & Mean Difference \\
\hline \multirow{2}{*}{ TOBINQ } & 0 & 1.457 & 0.503 & 0.898 & 2.641 & $0.018^{* * * *}$ \\
\hline & 1 & 1.439 & 0.480 & 0.898 & 2.641 & $(3.58)$ \\
\hline \multirow{2}{*}{$R O A$} & 0 & 0.033 & 0.036 & -0.103 & 0.117 & $0.041^{* * *}$ \\
\hline & 1 & -0.008 & 0.069 & -0.009 & 0.567 & $(20.49)$ \\
\hline \multirow{2}{*}{ GROW } & 0 & 0.690 & 1.179 & -0.399 & 3.072 & $-0.062^{* * *}$ \\
\hline & 1 & 0.752 & 1.243 & -0.293 & 4.656 & $(-8.73)$ \\
\hline \multirow{2}{*}{$L E V$} & 0 & 0.485 & 0.178 & 0.170 & 0.837 & $-0.118^{* * *}$ \\
\hline & 1 & 0.603 & 0.206 & 0.170 & 0.837 & $(-15.89)$ \\
\hline \multirow{2}{*}{$L N A$} & 0 & 1.478 & 1.236 & 0.314 & 3.098 & $0.796^{* * *}$ \\
\hline & 1 & 2.682 & 1.431 & 0.005 & 2.653 & $(15.42)$ \\
\hline \multirow{2}{*}{$A O$} & 0 & 0.796 & 0.403 & 0 & 1 & $-0.127^{* * *}$ \\
\hline & 1 & 0.923 & 0.266 & 0 & 1 & $(-5.86)$ \\
\hline \multirow{2}{*}{$B I G 4$} & 0 & 0.050 & 0.219 & 0 & 1 & 0.002 \\
\hline & 1 & 0.048 & 0.213 & 0 & 1 & $(0.15)$ \\
\hline \multirow{2}{*}{$H I$} & 0 & 19.288 & 13.779 & 2.554 & 28.494 & $5.474^{* * *}$ \\
\hline & 1 & 13.814 & 11.470 & 2.554 & 36.945 & $(9.75)$ \\
\hline \multirow{2}{*}{$S S$} & 0 & 0.247 & 0.241 & 0 & 0.750 & $-0.055^{* * *}$ \\
\hline & 1 & 0.302 & 0.255 & 0 & 0.810 & $(-3.50)$ \\
\hline \multirow{2}{*}{$T S$} & 0 & 0.456 & 0.147 & 0 & 1 & $0.0170^{*}$ \\
\hline & 1 & 0.438 & 0.153 & 0 & 1 & $(1.78)$ \\
\hline \multirow{2}{*}{$D U A L$} & 0 & 0.859 & 0.349 & 0 & 1 & -0.032 \\
\hline & 1 & 0.891 & 0.312 & 0 & 1 & $(-1.54)$ \\
\hline \multirow{2}{*}{ BSIZE } & 0 & 9.292 & 2.427 & 4 & 19 & -0.018 \\
\hline & 1 & 9.311 & 2.137 & 4 & 19 & $(-0.13)$ \\
\hline \multirow{2}{*}{ OSIZE } & 0 & 3.996 & 1.292 & 1 & 9 & -0.087 \\
\hline & 1 & 4.083 & 1.315 & 2 & 10 & $(-1.05)$ \\
\hline
\end{tabular}

Violating group is represented by $I D V=1$; non-violating group is represented by $I D V=0$.

${ }^{* * * *},{ }^{* *}$, and ${ }^{*}$ indicate significance at the $1 \%, 5 \%$, and $10 \%$ levels, respectively (two-tailed).

\section{Correlation Analysis}

Before carrying out the regressions, univariate correlation analysis is performed to examine whether there exist higher correlations between variables. Table 4 presents Pearson correlations for all samples in Panel A and only IDV samples in Panel B, respectively. In Panel A, correlations between LNA and BIG4 (0.379), HI and SS (0.564), HI and TS (-0.470), HI and DUAL (-0.062), SS and TS (-0.491), LNA and BSIZE (0.326), OSIZE and BSIZE (0.369), $Y E A R$ and TS (0.536), and YEAR and IND (0.697), are slightly higher; other correlations between variables are not material. In Panel B, high correlation is indeed a serious problem between some variables, for example, TNT and FINE (0.345), and YSPAN and VF (0.735). These high correlations are quite apparent by their nature. Thus, we decide against putting all these IDV characteristics variables in one regression. Further, to ensure the result is correct, we carry out a multicollinearity test, finding that all Variance Inflation Factors are less than 10. Hence, multicollinearity is not an important issue in this study. 
Table 4. Univariate Correlations ${ }^{4}$

\begin{tabular}{|c|c|c|c|c|c|c|c|c|}
\hline \multicolumn{9}{|c|}{ Panel A. Correlations for Violating and Non-violating Samples $(\mathrm{N}=15,966)$} \\
\hline Variable & TOBINQ & IDV & $R O A$ & GROW & $L E V$ & $L N A$ & $A O$ & BIG4 \\
\hline TOBINQ & 1 & & & & & & & \\
\hline$I D V$ & $-0.088^{* * *}$ & 1 & & & & & & \\
\hline$R O A$ & $0.026^{* *}$ & $0.040^{* * *}$ & 1 & & & & & \\
\hline GROW & $-0.037^{* * *}$ & $-0.088^{* * *}$ & $-0.027^{* * *}$ & 1 & & & & \\
\hline$L E V$ & $0.051^{* * *}$ & $0.019^{*}$ & $0.072^{* * *}$ & $-0.027^{* * *}$ & 1 & & & \\
\hline$L N A$ & $-0.332^{* * *}$ & $-0.154^{* * *}$ & $-0.079^{* * *}$ & $0.189^{* * *}$ & $-0.111^{* * *}$ & 1 & & \\
\hline$A O$ & $-0.100^{* * *}$ & $-0.291^{* * *}$ & $-0.032^{* * *}$ & $0.096^{* * *}$ & $-0.074^{* * *}$ & $0.206^{* * *}$ & 1 & \\
\hline BIG4 & $-0.120^{* * *}$ & $-0.057^{* * *}$ & -0.003 & $0.028^{* * *}$ & -0.006 & $0.379^{* * *}$ & $0.055^{* * *}$ & 1 \\
\hline$H I$ & $-0.182^{* * *}$ & $-0.097^{* * *}$ & -0.011 & $0.054^{* * *}$ & -0.016 & $0.166^{* * *}$ & $0.062^{* * *}$ & $0.087^{* * *}$ \\
\hline$S S$ & $-0.264^{* * *}$ & $-0.094^{* * *}$ & -0.012 & $0.035^{* * *}$ & -0.015 & $0.147^{* * *}$ & $0.050^{* * *}$ & $0.064^{* * *}$ \\
\hline$T S$ & $0.341^{* * *}$ & $0.017^{*}$ & -0.011 & $-0.053^{* * *}$ & 0.003 & $0.103^{* * *}$ & $0.049^{* * *}$ & $-0.023^{* *}$ \\
\hline$D U A L$ & $0.079^{* * *}$ & $0.032^{* * *}$ & -0.006 & -0.009 & $0.029^{* * *}$ & $-0.087^{* * *}$ & $-0.045^{* * *}$ & $-0.033^{* * *}$ \\
\hline$B S I Z E$ & $-0.135^{* * *}$ & $-0.060^{* * *}$ & $-0.021^{* *}$ & $0.044^{* * *}$ & -0.013 & $0.326^{* * *}$ & $0.054^{* * *}$ & $0.159^{* * *}$ \\
\hline OSIZE & $-0.108^{* * *}$ & $-0.052^{* * *}$ & -0.008 & $0.018^{*}$ & -0.015 & $0.251^{* * *}$ & $0.038^{* * *}$ & $0.097^{* * *}$ \\
\hline$I N D$ & $-0.090^{* * *}$ & $0.025^{* *}$ & 0.009 & $-0.018^{* *}$ & 0.014 & $0.142^{* * *}$ & $0.094^{* * *}$ & $0.081^{* * *}$ \\
\hline$Y E A R$ & $0.159^{* * *}$ & $0.044^{* * *}$ & 0.010 & -0.010 & 0.011 & $0.200^{* * *}$ & $0.103^{* * *}$ & $0.040^{* * *}$ \\
\hline
\end{tabular}

\begin{tabular}{|c|c|c|c|c|c|c|c|c|}
\hline \multicolumn{9}{|c|}{ Panal A continued } \\
\hline Variable & $H I$ & $S S$ & $T S$ & $D U A L$ & BSIZE & OSIZE & IND & $Y E A R$ \\
\hline$H I$ & 1 & & & & & & & \\
\hline$S S$ & $0.564^{* * *}$ & 1 & & & & & & \\
\hline$T S$ & $-0.470^{* * *}$ & $-0.491^{* * *}$ & 1 & & & & & \\
\hline$D U A L$ & $-0.062^{* * *}$ & $-0.099^{* * *}$ & 0.016 & 1 & & & & \\
\hline$B S I Z E$ & 0.001 & $0.117^{* * *}$ & $-0.038^{* * *}$ & $-0.059^{* * *}$ & 1 & & & \\
\hline OSIZE & $0.061^{* * *}$ & $0.195^{* * *}$ & $-0.055^{* * *}$ & $-0.064^{* * *}$ & $0.369^{* * *}$ & 1 & & \\
\hline$I N D$ & $-0.136^{* * *}$ & $-0.154^{* * *}$ & $0.258^{* * *}$ & 0.004 & $-0.069^{* * *}$ & $-0.082^{* * *}$ & 1 & \\
\hline$Y E A R$ & $-0.217^{* * *}$ & $-0.297^{* * *}$ & $0.536^{* * *}$ & $0.028^{* * *}$ & $-0.041^{* * *}$ & $-0.082^{* * *}$ & $0.697^{* * *}$ & 1 \\
\hline
\end{tabular}

\begin{tabular}{|c|c|c|c|c|c|c|c|}
\hline \multicolumn{8}{|c|}{ Panel B. Correlations for IDV Sample $(\mathrm{N}=1623)$} \\
\hline Variable & TOBINQ & IPAF & $T N T$ & FINE & $N A T$ & $\boldsymbol{V F}$ & YSPAN \\
\hline TOBINQ & 1 & & & & & & \\
\hline$I P A F$ & $-0.035^{* *}$ & 1 & & & & & \\
\hline$T N T$ & $-0.078^{* *}$ & $0.245^{* *}$ & 1 & & & & \\
\hline FINE & $-0.257^{* * *}$ & $0.569^{* * *}$ & $0.345^{* * *}$ & 1 & & & \\
\hline$N A T$ & $-0.077^{* *}$ & $0.537^{* *}$ & $0.146^{* *}$ & $0.383^{* * *}$ & 1 & & \\
\hline$V F$ & $-0.046^{* *}$ & $0.382^{* *}$ & $0.534^{* *}$ & $0.732^{* * *}$ & $0.343^{* *}$ & 1 & \\
\hline YSPAN & $-0.090^{* * *}$ & $0.412^{* * *}$ & $0.463^{* * *}$ & $0.456^{* * *}$ & $0.435^{* * *}$ & $0.735^{* * *}$ & 1 \\
\hline
\end{tabular}

${ }^{* * *}$, and ${ }^{*}$ indicate significance at the $1 \%, 5 \%$, and $10 \%$ levels, respectively (two-tailed).

\section{Regression}

Table 5 provides results of equation (1) from Ordinary Least Squares (OLS) regression of firm value at IDV variables and control variables for IDV and non-violating groups. In Table 5, the dependent variable is TOBINQ. Column (1) analyzes how IDV affects firm value. As expected, we find a significantly negative estimated coefficient of IDV at the $1 \%$ level, which indicates that firm value in IDV firms is much lower than firm value in non-violating firms. Column (2) of Table 5 shows the results after controlling for firm characteristics. The negative effect of IDV on firm value continues to be statistically significant. For firm characteristics, we detect, surprisingly, a significantly negative effect of $A O$ and $B I G 4$ on $T O B I N Q$, which may be due to the fact that auditor industry has not been fully accepted by capital markets in China. After controlling for industry and year difference in Column (3), we find similar results. Thus, $\mathrm{H} 1$ is supported, which means that means firm value in violating firms is much lower than firm value in non-violating firms.

\footnotetext{
${ }^{4}$ For reasons of limited space, industry variables are untablated; they have no high correlations with other variables. Control variables are not tabulated in Panel B, for space considerations, which do not have high correlations with IDV characteristics variables.
} 
Table 5. OLS Regression Results for All Samples

\begin{tabular}{|c|c|c|c|c|}
\hline \multicolumn{5}{|c|}{ Dependent variable is $T O B I N Q$} \\
\hline Variable & Sign & (1) & (2) & (3) \\
\hline \multirow{2}{*}{ constant } & & $1.729^{* * *}$ & $2.236^{* * *}$ & $5.046^{* * *}$ \\
\hline & & $(12.92)$ & $(43.61)$ & $(28.85)$ \\
\hline \multirow{2}{*}{$I D V$} & \multirow{2}{*}{-} & $-0.218^{* * *}$ & $-0.106^{* * *}$ & $-0.068^{* * *}$ \\
\hline & & $(-8.78)$ & $(-4.49)$ & $(-4.95)$ \\
\hline \multirow{2}{*}{$R O A(\%)^{5}$} & \multirow{2}{*}{+} & & $2.911^{* * *}$ & $0.020^{* * *}$ \\
\hline & & & $(24.86)$ & $(4.11)$ \\
\hline \multirow{2}{*}{ GROW (\%) } & \multirow[b]{2}{*}{-} & & $-0.002^{*}$ & -0.001 \\
\hline & & & $(-0.30)$ & $(-0.07)$ \\
\hline \multirow{2}{*}{$L E V$} & \multirow{2}{*}{+} & & $0.069^{* * *}$ & $0.066^{* * *}$ \\
\hline & & & $(16.17)$ & $(16.44)$ \\
\hline \multirow{2}{*}{$L N A$} & \multirow[b]{2}{*}{-} & & $-0.159^{* * * *}$ & -0.191 \\
\hline & & & $(-30.11)$ & $(-33.84)$ \\
\hline \multirow{2}{*}{$A O$} & \multirow{2}{*}{+} & & $-0.450^{* * *}$ & $-0.171^{* * *}$ \\
\hline & & & $(-8.76)$ & $(-8.08)$ \\
\hline \multirow{2}{*}{$B I G 4$} & \multirow[b]{2}{*}{+} & & -0.010 & -0.001 \\
\hline & & & $(-0.48)$ & $(-0.05)$ \\
\hline \multirow{2}{*}{$H I$} & \multirow{2}{*}{-} & & $-0.671^{* * *}$ & $-0.502^{* * *}$ \\
\hline & & & $(-6.74)$ & $(-5.24)$ \\
\hline \multirow{2}{*}{$S S$} & \multirow[b]{2}{*}{-} & & $-0.473^{* * *}$ & $-0.358^{* * *}$ \\
\hline & & & $(-18.00)$ & $(-13.52)$ \\
\hline \multirow{2}{*}{$T S$} & \multirow{2}{*}{+} & & $0.001^{* * *}$ & $0.0001^{* * *}$ \\
\hline & & & $(8.06)$ & $(5.99)$ \\
\hline \multirow{2}{*}{$D U A L$} & \multirow{2}{*}{+} & & $0.045^{* *}$ & $0.040^{* *}$ \\
\hline & & & $(2.75)$ & $(2.55)$ \\
\hline \multirow{2}{*}{$B S I Z E$} & \multirow{2}{*}{-} & & $-0.006^{*}$ & $-0.005^{*}$ \\
\hline & & & $(-2.12)$ & $(-1.79)$ \\
\hline \multirow{2}{*}{$O S I Z E$} & \multirow{2}{*}{-} & & $-0.008^{*}$ & $-0.011^{* *}$ \\
\hline & & & $(-2.07)$ & $(-2.65)$ \\
\hline$I N D$ & & & & Controlled \\
\hline YEAR & & & & Controlled \\
\hline Observations & & 15966 & 15966 & 15966 \\
\hline F-value & & 77.01 & 84.18 & 82.92 \\
\hline Adj. $\mathrm{R}^{2}$ & & 0.076 & 0.078 & 0.192 \\
\hline
\end{tabular}

$* * *, * *$, and $*$ indicate significance at the $1 \%, 5 \%$, and $10 \%$ levels, respectively (two-tailed).

Table 6 shows the results of equation (2) from OLS regression of firm value at violation characteristics and control variables for IDV groups, to test $\mathrm{H} 2$ to $\mathrm{H} 5$. Further, the dependent variable is TOBINQ. Column (1) analyzes the relationship between IPAF and TOBINQ; the results show that decreasing firm value caused by IDV is more pronounced for firms with inflated profit or asset fabrication than for firms with other violation types. Thus, H2a is supported. Column (2) of Table 6 shows the significantly negative results for variable $T N T$, which means that firm value is negatively related to the total number of violation types. Thus, $\mathrm{H} 2 \mathrm{~b}$ is supported.

Column (3) shows the significantly negative relationship between FINE and TOBINQ; thus this relationship support H3a. Column (4) analyzes how admonishment types affect firm value. Thus, H3b is supported. That is, firm value is negatively related to the total number of admonishment types.

Column (5) shows the significantly negative relationship between violations frequency and $T O B I N Q$, thus supporting H4: firm value of IDV companies is negatively related to violation times. Thus, H4 is supported.

\footnotetext{
${ }^{5}$ Due to smaller coefficients of $R O A$ and GROW, the original is multiplied by 100 . The same method is used in Table 7. The coefficient of ROA is negative because two observations of $R O A$ are extreme outliers, influencing the expected sign. After we drop these two observations, the sign of $R O A$ is significantly positive without influencing other coefficients' sign.
} 
Column (6) analyzes how firm value is negatively related to year span between a violation and its exposure. Thus, H5 is supported, that is, firm value is negatively related to year span between a violation and its exposure.

To sum up, all hypotheses are supported. Therefore, IDV can bring about serious damage to firm value.

Table 6. OLS Regression Results in IDV Group

\begin{tabular}{|c|c|c|c|c|c|c|c|}
\hline \multicolumn{8}{|c|}{ Dependent variable is $T O B I N Q$} \\
\hline Variable & Sign & (1) $\mathbf{H 2 a}$ & (2) $\mathrm{H} 2 \mathrm{~b}$ & (3) H3a & (4) H3b & (5) $\mathrm{H} 4$ & (6) $\mathrm{H5}$ \\
\hline \multirow{2}{*}{ constant } & & $11.967^{* *}$ & $13.399^{* * *}$ & $14.979^{* * *}$ & $12.243^{* * *}$ & $13.256^{* * *}$ & $14.103^{* *}$ \\
\hline & & $(2.26)$ & $(3.61)$ & $(3.85)$ & $(3.47)$ & $(3.05)$ & $(3.23)$ \\
\hline \multirow{2}{*}{$I P A F$} & \multirow{2}{*}{-} & $-0.227^{* *}$ & & & & & \\
\hline & & $(-2.25)$ & & & & & \\
\hline \multirow{2}{*}{$T N T$} & \multirow[b]{2}{*}{-} & & $-0.035^{* * *}$ & & & & \\
\hline & & & $(-2.96)$ & & & & \\
\hline \multirow{2}{*}{ FINE } & \multirow{2}{*}{-} & & & $-0.034^{* * *}$ & & & \\
\hline & & & & $(-3.15)$ & & & \\
\hline \multirow{2}{*}{$N A T$} & \multirow{2}{*}{-} & & & & $-0.012^{* * *}$ & & \\
\hline & & & & & $(-5.18)$ & & \\
\hline \multirow{2}{*}{$V F$} & \multirow[b]{2}{*}{-} & & & & & $-0.039^{* *}$ & \\
\hline & & & & & & $(-2.27)$ & \\
\hline \multirow{2}{*}{$Y S P A N$} & \multirow{2}{*}{-} & & & & & & $-0.004^{* *}$ \\
\hline & & & & & & & $(-2.15)$ \\
\hline Observations & & 1623 & 1623 & 1623 & 1623 & 1623 & 1623 \\
\hline F-value & & 15.68 & 15.22 & 15.12 & 15.18 & 15.44 & 15.11 \\
\hline Adj. $\mathrm{R}^{2}$ & & 0.368 & 0.360 & 0.359 & 0.360 & 0.362 & 0.358 \\
\hline
\end{tabular}

\section{ADDITIONAL ANALYSES}

In this section, we substitute several variables in equations (1) and (2), such as substitute return on equity (ROE) for TOBINQ. The findings, shown in Table 7, are consistent with the conclusions in Table 5. Thus, it is again shown that firm value in violating firms is significantly lower than firm value in non-violating firms. 
Table 7. OLS Regression Results for All Samples

\begin{tabular}{|c|c|c|c|c|}
\hline \multicolumn{5}{|c|}{ Dependent variable is ROE } \\
\hline$R O E$ & \multirow{3}{*}{ Sign } & (1) & (2) & (3) \\
\hline \multirow{2}{*}{ constant } & & $2.369^{* * *}$ & $4.966^{* * *}$ & $4.456^{* * *}$ \\
\hline & & $(4.54)$ & $(24.61)$ & $(34.05)$ \\
\hline \multirow{2}{*}{$I D V$} & \multirow{2}{*}{-} & $-0.575^{* * *}$ & $-2.457^{* * *}$ & $-1.434^{* * *}$ \\
\hline & & $(-5.37)$ & $(-5.34)$ & $(-4.23)$ \\
\hline \multirow{2}{*}{$R O A(\%)$} & \multirow{2}{*}{+} & & $4.534^{* * *}$ & $1.023^{* * *}$ \\
\hline & & & $(3.86)$ & $(2.98)$ \\
\hline \multirow{2}{*}{ GROW (\%) } & \multirow{2}{*}{ - } & & -0.001 & -0.002 \\
\hline & & & $(-0.04)$ & $(-0.05)$ \\
\hline \multirow{2}{*}{$L E V$} & \multirow{2}{*}{+} & & $0.102^{* * *}$ & $0.065^{* * *}$ \\
\hline & & & $(11.19)$ & $(14.01)$ \\
\hline \multirow{2}{*}{$L N A$} & \multirow{2}{*}{-} & & $-0.456^{* * *}$ & -0.345 \\
\hline & & & $(-23.11)$ & $(-13.56)$ \\
\hline \multirow{2}{*}{$A O$} & \multirow{2}{*}{+} & & $-0.345^{* * *}$ & $-0.443^{* * *}$ \\
\hline & & & $(-5.66)$ & $(-4.54)$ \\
\hline \multirow{2}{*}{$B I G 4$} & \multirow{2}{*}{+} & & -0.009 & -0.012 \\
\hline & & & $(-0.39)$ & $(-0.25)$ \\
\hline \multirow{2}{*}{$H I$} & \multirow[b]{2}{*}{-} & & $-0.561^{* * *}$ & $-0.562^{* * *}$ \\
\hline & & & $(-6.64)$ & $(-5.65)$ \\
\hline \multirow{2}{*}{$S S$} & \multirow{2}{*}{-} & & $-0.345^{* * *}$ & $-0.334^{* * *}$ \\
\hline & & & $(-18.89)$ & $(-16.62)$ \\
\hline \multirow{2}{*}{$T S$} & \multirow{2}{*}{+} & & $0.001^{* * *}$ & $0.001^{* * *}$ \\
\hline & & & $(8.89)$ & $(6.98)$ \\
\hline \multirow{2}{*}{$D U A L$} & \multirow{2}{*}{+} & & $0.078^{* * *}$ & $0.009^{* * *}$ \\
\hline & & & $(3.75)$ & $(3.15)$ \\
\hline \multirow{2}{*}{$B S I Z E$} & \multirow[b]{2}{*}{-} & & $-0.009^{* *}$ & $-0.002^{*}$ \\
\hline & & & $(-2.66)$ & $(-1.79)$ \\
\hline \multirow{2}{*}{ OSIZE } & \multirow{2}{*}{-} & & $-0.002^{*}$ & $-0.011^{* *}$ \\
\hline & & & $(-2.17)$ & $(-2.75)$ \\
\hline$I N D$ & & & & controlled \\
\hline$Y E A R$ & & & & controlled \\
\hline Observations & & 15966 & 15966 & 15966 \\
\hline F-value & & 67.01 & 45.78 & 54.92 \\
\hline Adj. $\mathrm{R}^{2}$ & & 0.165 & 0.034 & 0.534 \\
\hline
\end{tabular}

${ }^{* * *},{ }^{* *}$, and ${ }^{*}$ indicate significance at the $1 \%, 5 \%$, and $10 \%$ levels, respectively (two-tailed).

The results in Table 8 below show no significant difference from the results displayed in Table 6. All hypotheses are proved. Thus, IDV with violation characteristics (IPAF, TNT, FINE, NAT, VF, YSPAN) can bring about serious damage to firm value. 
Table 8. OLS Regression Results for IDV Group

\begin{tabular}{|c|c|c|c|c|c|c|c|}
\hline \multicolumn{8}{|c|}{ Dependent variable is $R O E$} \\
\hline Variable & Sign & (1) $\mathrm{H} 2 \mathrm{a}$ & (2) H2b & (3) H3a & (4) $\mathrm{H3b}$ & (5) $\mathrm{H} 4$ & (6) H5 \\
\hline constant & & $\begin{array}{l}17.457^{* *} \\
(2.56)\end{array}$ & $\begin{array}{l}12.342^{* * *} \\
(3.61)\end{array}$ & $\begin{array}{l}12.834^{* * *} \\
(3.85)\end{array}$ & $\begin{array}{l}15.463^{* * *} \\
(3.47)\end{array}$ & $\begin{array}{l}15.576^{* * *} \\
(3.05)\end{array}$ & $\begin{array}{l}16.457^{* * *} \\
(3.23)\end{array}$ \\
\hline$I P A F$ & - & $\begin{array}{l}-0.457^{\text {*** }} \\
(-3.15)\end{array}$ & & & & & \\
\hline$T N T$ & - & & $\begin{array}{l}-0.025^{* * *} \\
(-3.45)\end{array}$ & & & & \\
\hline FINE & - & & & $\begin{array}{l}-0.012^{* * *} \\
(-3.23)\end{array}$ & & & \\
\hline$N A T$ & - & & & & $\begin{array}{l}-0.034^{* * *} \\
(-4.18)\end{array}$ & & \\
\hline$V F$ & - & & & & & $\begin{array}{l}-0.034^{* *} \\
(-2.26)\end{array}$ & \\
\hline YSPAN & - & & & & & & $\begin{array}{l}-0.003^{* *} \\
(-2.35) \\
\end{array}$ \\
\hline Observations & & 1623 & 1623 & 1623 & 1623 & 1623 & 1623 \\
\hline F-value & & 16.56 & 15.99 & 15.56 & 15.45 & 15.77 & 15.14 \\
\hline Adj. $\mathrm{R}^{2}$ & & 0.456 & 0.876 & 0.434 & 0.356 & 0.335 & 0.478 \\
\hline
\end{tabular}

${ }^{* * *}{ }^{* *}$, and ${ }^{*}$ indicate significance at the $1 \%, 5 \%$, and $10 \%$ levels, respectively (two-tailed).

\section{CONCLUSIONS}

We identify a sample of 1,623 observations of IDV in the period 2000-2014. These enforcement actions expose IDVs committed by firms. In brief, we find that firm value in violating firms is significantly lower than firm value in non-violating firms. Further, we find IDV with violation characteristics can bring about serious damage to firm value. Specifically, IDV related to inflated profit and asset fabrication have a more damaging effect on firm value; fines and other admonishment types, violation frequency and time span between the year of violation and the year of CSRC enforcement action are negatively related to firm value. Our findings suggest that some kinds of IDV have potentially adverse economic consequences.

The evidence uncovered in this paper holds policy implications for regulators. Our findings that violating firms have significantly lower firm value than non-violating firms support the long-term effects of violation. Thus, the CSRC should issue severe punishments to violating firms to protect investor interests. This study also holds research implications. The findings of this paper indicate that IDV with violation characteristics can bring about serious damage to firm value. Thus, securities regulatory bureaus in every province should inspect firms jointly with the CSRC to decrease firm violations. Future research should examine the relations between violating firms with violating characteristics and stock price from other perspectives.

\section{ACKNOWLEDGEMENTS}

This research was supported by national natural science foundation of China $(71572144 ; 71502138 ; 71102095)$, and China postdoctoral science foundation (2014M550505, 2015T81041, 2013M542313).

\section{AUTHOR BIOGRAPHY}

Bin $\mathbf{L i}$ is a post doctor in School of Management and an associate professor in School of Economics and Finance, Xi'an Jiaotong University, Shaanxi, Xi’an, P. R. China. E-mail:libin2010@mail.xjtu.edu.cn

\section{REFERENCES}

Anderson, D.M. (1999). Taking stock in China: Company disclosure and information in China's stock markets. Georgetown Law Journal, 88, 1919-1952.

Chen, G., Firth, M., Gao, D.N., and Rui, O.M. (2005). Is China's securities regulatory agency a toothless tiger? Evidence from enforcement actions. Journal of Accounting and Public Policy, 24 (6), 451-488. 
Chiyachantana, C., N. Taechapiroontong, C. Jiang, and R. Wood. (2004). The impact of regulation fair disclosure on information asymmetry and trading: an intraday analysis, The Financial Review, 39(4), 549-577.

Demiroglu, C. and C. James. (2010). The information content of bank loan covenants, Review of Financial Studies, 23(10), 37003737.

Dichev, I. and D. Skinner. (2002). Large-sample evidence on the debt covenant hypothesis, Journal of Accounting Research, 40(4), 1091-1123.

Eleswarapu, V., R. Thompson, and K. Venkataraman. (2004). The impact of regulation fair disclosure: trading costs and information asymmetry, Journal of Financial and Quantitative Analysis, 39(2), 209-225.

Feroz, E.H., Park, K., and Pastena, V.S. (2008). The financial and market effects of the SEC's accounting and auditing enforcement releases. Journal of Accounting Research, 29 (Supplement), 107-142.

Ferris, S., Kumar, R., and Wolfe, A.G. (1992). The effects of SEC-ordered suspensions on returns, volatility, and trading volume. The Financial Review, 27(1), 1-34.

Gintschel, A., and S. Markov. (2004). The effectiveness of regulation FD, Journal of Accounting and Economics, 37(3), $293-314$.

Gopalakrishnan, V. and M. Parkash. (1995). Borrower and lender perceptions of accounting information in corporate lending agreements, Accounting Horizons, 9(1), 13-26.

Griffin, P. A., Lont, D. H., and McClune, K. (2014). Insightful insiders? Insider trading and stock return around debt covenant violation disclosures. Abacus, 50(2), 117-145.

Healey, P. M., and K. G. Palepu. (2001). Information asymmetry, corporate disclosure, and the capital markets: A review of the empirical disclosure literature, Journal of Accounting and Economics 31(1), 405-440.

Heflin, F., and Hsu, C., (2008). The impact of the SEC's regulation of non-GAAP disclosures. Journal of Accounting and Economics 46 (2), 349-365.

Howe,J.S.and Schlarbaum G. (1986). SEC trading suspensions: Empirical evidence, Journal of Financial and Quantitative Analysis, 21 (3), 323-333.

Karpoff, J.M., Lee, D.S., and Martin, G.S. (2008). The cost to firms of cooking the books. Journal of Financial and Quantitative Analysis, 43 (3), 581-611.

Lepone, A., H. Leung, and J. Li. (2013). Unequal access to analyst research, Australian Journal of Management, 38(2), $253-277$.

Muradoglu, Y. G., and Clark Huskey, J. (2008). The impact of SEC litigation on firm value. Available at SSRN 1094948.

Murphy, D.L., Shrieves, R.E., and Tibbs, S.L. (2009). Understanding the penalties associated with corporate misconduct an empirical examination of earnings and risk. Journal of Financial and Quantitative Analysis, 44 (1), 55-83.

Nourayi, M. M. (1995). Stock price responses to the SEC's enforcement actions. Journal of Accounting and Public Policy, 13(4), 333-347.

Nourayi, M. (1995). Economic conditions and the SEC's enforcement process. Journal of Applied Business Research, 11(2): 2328.

Porta, R.L., Lopez-de-Silanes, F., and Shleifer, A. (1999). Corporate ownership around the world. The Journal of Finance 54 (2), 471-517.

Shroff, N., Sun, A. X., White, H. D., and Zhang, W. (2013). Voluntary disclosure and information asymmetry: Evidence from the 2005 securities offering reform. Journal of Accounting Research, 51(5), 1299-1345.

Smith, D. B., Stettler, H., and Beedles, W. (1984). An investigation of the information content of foreign sensitive payment disclosures. Journal of accounting and Economics, 6(2), 153-162.

Wei, Z., Xie, F., and Zhang, S. (2005). Ownership structure and firm value in China's privatized firms: 1991-2001. Journal of financial and quantitative analysis, 40(01), 87-108.

Yao, Y., Xu, L., and Liu, Z. (2010). Taking away the voting powers from controlling shareholders: evidence from the Chinese securities market. Journal of International Financial Management \& Accounting, 21(3), 187-219.

Zhu, Y., and Gippel, J. (2015). Informed trading on debt covenant violations: the long and short of it. Accounting \& Finance, forthcoming. 